J. Clin. Chem. Clin. Biochem.

Vol. 24, 1986, pp. 993-999

(C) 1986 Walter de Gruyter \& Co. Berlin - New York

\title{
The Age Dependency of the Creatinine-Related Concentration of Ribonucleosides in Human Urine
}

\author{
By J. Müller-Wickop, H. Lorenz, K. Winkler and N. Erb \\ Universitätskinderklinik, Abt. Hämatologie und Onkologie (Direktor: Prof. G. Landbeck) Hamburg
}

(Received March 21/July 4, 1986)

\begin{abstract}
Summary: We investigated the urinary excretion of ribonucleosides and an unidentified substance in 345 healthy probands from the age of a few weeks to 40 years. The concentration of ribonucleosides, related to the corresponding concentration of creatinine, decreases until nearly 20 years and remains constant between 20 and 40 years. The polynomial functions describing this dependency are presented. The biological significance of our findings is briefly discussed.
\end{abstract}

\section{Die Altersabhängigkeit der Kreatinin-bezogenen Konzentration von Ribonucleosiden im menschlichen Urin}

Zusammenfassung: Die renale Ausscheidung von Ribonucleosiden und einer noch nicht identifizierten Substanz wurde bei 345 gesunden Probanden unterschiedlichen Alters (wenige Wochen bis 40 Jahre) untersucht. Die auf den Kreatiningehalt der Urinprobe bezogene Konzentration nimmt etwa bis zum 20. Lebensjahr ab und bleibt dann bis zum 40. Lebensjahr konstant. Diese Altersabhängigkeit kann mit Hilfe von Polynomialfunktionen beschrieben werden. Die biologische Bedeutung der Ergebnisse wird diskutiert.

\section{Introduction}

It has been known for many years that degradation products of nucleic acids are excreted in urine. So far, 50 purine and pyrimidine derivatives have been identified (for general reviews see 1.c. 1-3).

The major nucleosides and bases released in the catabolism of nucleic acids are mainly reincorporated (salvage pathway) or metabolized. On the other hand, many of the modified ones, like pseudouridine and methylated guanine derivatives (which have been found chiefly in tRNA) seem to be excreted completely $(4,5)$. Changes in the normal pattern of excretion were seen in tumour growth $(6-8)$ and disorders of metabolism $(9-11)$.

Only a little information is available concerning the age-dependent excretion of degradation products of nucleic acids. Borek et al. (4) and Heldman et al. (12) have observed higher creatinine-related nucleoside concentrations in children than in adults. However, they investigated only small groups. Schöch et al. (13) found "a narrow correlation between the excretion of nucleobases and growth velocity". In this investigation nucleosides were hydrolysed and analysed together with the native excreted bases.

We developed a new procedure which allows the determination of ribonucleosides as well as nucleobases. Thus the aim of our work was to examine the age-dependency of excretion of both substances as a basis for diagnosis. In the present paper we present the results for the nucleoside analysis.

\section{Experimental}

Chemicals

The nucleosides, pseudouridine $(\Psi)$, cytidine $(C)$, uridine $(U)$, 5-aminoimidazole-4-carboxamide riboside, 1-methyladenosine $\left(\mathrm{m}^{1} \mathrm{~A}\right), 5$-methylcytidine $\left(\mathrm{m}^{5} \mathrm{C}\right)$, inosine (I), guanosine $(\mathrm{G}), 3$ methyluridine $\left(\mathrm{m}^{3} \mathrm{U}\right), 1$-methylinosine $\left(\mathrm{m}^{1} \mathrm{I}\right), 1$-methylguanosine $\left(m^{1} G\right), 2$-methylguanosine $\left(m^{2} G\right)$, adenosine $(A), N^{2}, N^{2}$. 
dimethylguanosine $\left(\mathrm{m}_{2}^{2} \mathrm{G}\right)$ and tubercidine were purchased from Sigma, Munich, and used without further purification. 2-pyridone-5-carboxamide- $\mathrm{N}^{1}$-ribofuranoside was a gift from Prof. Schlimime, Kiel, GFR. Stock solutions of the nucleosides were prepared in $0.1 \mathrm{~mol} / \mathrm{l}$ formic acid (concentration between 3.2 and $5.3 \mathrm{mmol} / \mathrm{l}$ ). We purchased methanol. ammonium hydroxide, formic acid and ammonium dihydrogen phosphate (all of p. a. grade) from Merck, Darmstadt, GFR, and ammonium formate (pure) from Riedel de Haën, Hannover. Dowex 1X8 and Affi Gel 601 (Sigma, Munich) were used in the prefractionation step. Water was double distilled. All buffers were degassed and filtered through a $0.5 \mu \mathrm{m}$ membrane filter (HVLP 04700, Millipore, Bedford).

\section{Samples}

Single urines from 345 probands of 0 to 40 years of age (tab. 1) were collected and stored at $-20^{\circ} \mathrm{C}$ until analysis. The urines from adults were mainly supplied by the blood donor centre of the University hospital Hamburg-Eppendorf (volunteer urine given before the first blood donation). Infant urines were kindly supplied by the Forschungsinstitut für Kinderernährung, Dortmund, GFR.

Tab. 1. Age and sex distribution of the included healthy probands.

\begin{tabular}{lcclllll}
\hline Sex & \multicolumn{1}{l}{ Age (years) } & & & & \\
\cline { 2 - 7 } & $0-1$ & $1-5$ & $5-$ & $10-$ & $15-$ & $20-$ & $0-40$ \\
& & & 10 & 15 & 20 & 40 & \\
\hline Female & 0 & 22 & 26 & 42 & 26 & 33 & 149 \\
Male & 29 & 17 & 25 & 42 & 35 & 48 & 196 \\
\hline
\end{tabular}

All probands were clinically healthy. The urines were screened for $\mathrm{pH}$, protein, glucose, ketones, nitrite and erythrocytes (Labstix, Ames, Frankfurt). Samples with abnormal values were discarded.

To determine the urinary creatinine concentration, we used the Creatinine Analyser 2 (Beckman, Munich), and each sample was analysed in duplicate.

\section{Sample clean-up}

The equipment and procedure for the sample clean-up, described in detail elsewhere $(14,15)$, are depicted in figure 1.

Briefly, the deproteinized urine is applied to column 1 (strong anion exchanger). UV-absorbing impurities are eliminated $\left(\mathrm{H}_{2} \mathrm{O} / \mathrm{MeOH}, 80: 20 ; \mathrm{pH} 9\right)$, then the nucleosides and nucleobases are eluted together $(0.1 \mathrm{~mol} / 1 \mathrm{HCOOH} / 0.15 \mathrm{~mol} / \mathrm{l}$ $\mathrm{HCOONH}_{4}$ ) and transferred on line to column 2, wich contains an affinity gel for cis-diols (Affi Gel 601). Simultaneously the eluate is mixed with an alkaline buffer $\left(1 \mathrm{~mol} / 1 \mathrm{NH}_{4} \mathrm{OH} / 0.15\right.$ $\mathrm{mol} / 1 \mathrm{HCOONH}{ }_{4}$ ). Under these conditions, the nucleosides are adsorbed on the gel. The bases are not retained and collected separately. Then the nucleosides are eluted with $0.1 \mathrm{~mol} / \mathrm{l}$ $\mathrm{HCOOH}$ (fig. 1).

In contrast to Sander et al. (15), we did not lyophilize the nucleoside fraction before the HPLC determination and pseudouridine was determined in this fraction (see below).

\section{High performance liquid chromatography \\ Equipment}

The HPLC system consisted of a pump $740 \mathrm{~B}$ with pump control and pressure monitor (Spectra Physics, Darmstadt), an UV detector model 440 (Waters, Königsstein), and an integrator

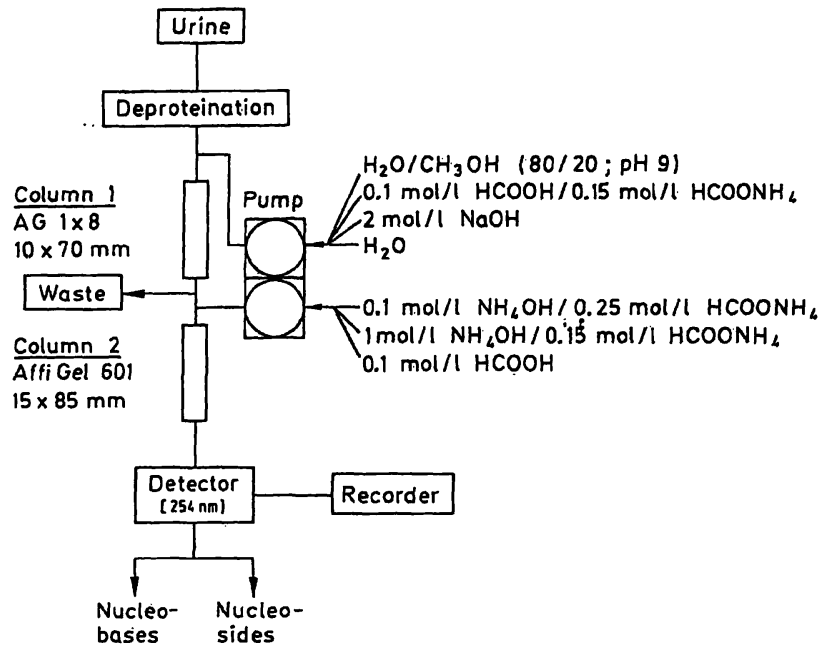

Fig. 1. Scheme of analysis for the simultaneous extraction of ribonucleosides and nucleobases from urine.

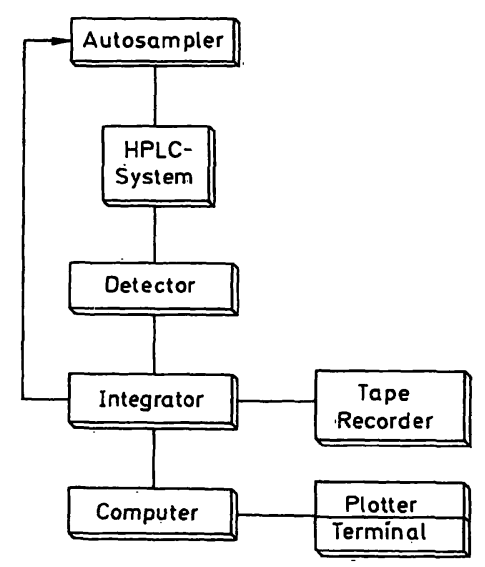

Fig. 2. Equipment for the HPLC analysis and processing of data.

SP 4100 (Spectra Physics), controlling the autosampler (ASI 120; ABC, Munich). The stainless steel columns (Knauer, Berlin) were heated by an appropriate metal block in combination with a thermostat (model FK, Haake, Berlin).

\section{Analytical conditions}

Pseudouridine: Column $250 \times 4.6 \mathrm{~mm}, \mu$ Bondapak $\mathrm{C}_{18}$ (Waters), precolumn $50 \times 4.6 \mathrm{~mm}$, Porasil $40 \mu$ (Waters); mobile phase: $0.01 \mathrm{~mol} / 1 \mathrm{NH}_{4} \mathrm{H}_{2} \mathrm{PO}_{4}$ with $1 \% \mathrm{MeOH}$; flow rate $1 \mathrm{ml} / \mathrm{min}$; temperature $30^{\circ} \mathrm{C}$; detection at $254 \mathrm{~nm}, 0.05$ absorbance units full scale; detector attenuation: 1024, sample volume: $50 \mu \mathrm{l}$.

Other nucleosides: Column as for Pseudouridine; mobile phase: $0.1 \mathrm{~mol} / 1 \mathrm{HCOONH}$, adjusted to $\mathrm{pH} 5$ with $\mathrm{HCOOH}$; flow rate: $1.6 \mathrm{ml} / \mathrm{min}$; temperature: $40^{\circ} \mathrm{C}$; detection at $254 \mathrm{~nm}, 0.02$ absorbance units full scale; detector attenuation: 1024; sample volume: $500 \mu \mathrm{l}$.

\section{Processing of data}

The peak data (height and retention time) were transferred from the integrator to a PDP 11/34 computer (Digital Ëquipment, Munich) as shown in figure 2 . The peaks were identified according to their retention time related to the internal standard 
tubercidine (window $\pm 3 \%$ ) and quantified, using the internal standard method, with respect to the dilution factor and creatinine level. In a similar way we calculated an as yet unidentified substance " $\mathrm{S}$ ", assuming an imaginary concentration in the calibration standard. In preliminary investigations the peaks were identified by co-chromatography of authentic nucleosides in control urines.

The final values were combined in a data bank with probands' personal data to determine different groups for statistical analysis by deliberate selection criteria.

We used the method of interpolating cubical spline function to calculate the curves for the concentration of ribonucleosides and creatinine versus age $(17,18)$. The fitted curve for each compound was calculated as a polynomial of the 5th degrec from 1 to $\mathbf{4 0}$ years.

The correlations in pairs between the concentration of ribonucleosides in adults were calculated according to Müller et al. (7).

The required programs were newly developed or they werc extensions from already existing program listings (SPSS program package, SPSS Corp., Chicago).

The system was automated from the HPLC analysis to the statistical analysis of the obtained data.

\section{Results}

The recoveries of the nucleosides depicted in figure $3 \mathrm{a}$ are nearly complete with the exception of $\mathrm{m}^{1} \mathrm{~A}$ and $\mathrm{m}^{1} \mathrm{I}$, which suffer rather large losses during the extraction step (15), due to their instability in alkaline solution (16). Fourteen natural nucleosides and the internal standard tubercidine are well separated in the calibration standard. However, $U, m^{5} C$ and $m^{2} G$ coelute with other urinary UV-absorbing compounds.

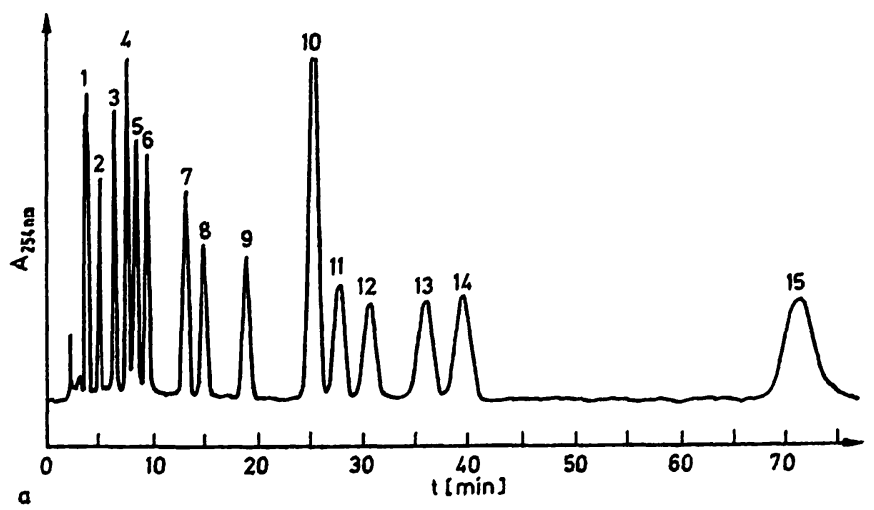

Fig. 3. Reversed-phase HPLC separation of ribonucleosides. a) Separation of a synthetic mixture $(100 \mu \mathrm{l} ; 0.1-0.25$ nmol of each nucleoside, $0.8 \mathrm{nmol}$ of tubercidinc).

b) Separation of the nucleoside fraction of a bealthy adult $(100 \mu \mathrm{l})$, obtained in the sample clean-up step. Chromatographic conditions: $\mu$ Bondapak $\mathrm{C}_{18}(250 \times 4.6 \mathrm{~mm})$, precolumn Porasil $40 \mu, 50 \times 4.6 \mathrm{~mm}$ ), eluent: $0.1 \mathrm{~mol} / 1 \mathrm{NH}_{4} \mathrm{COOH}, \mathrm{pH} 5$; flow rate $1.6 \mathrm{ml} / \mathrm{min}$; detection at $254 \mathrm{~nm}$, absorbance units full scale 0.02 ; integrator attenuation 128.

The following ribonucleosides were included for the age-dependent urinary excretion analysis: $\Psi, C, m^{1} G$, $A, m_{2}^{2} \mathrm{G}$, and an as yct unidentified substance " $\mathrm{S}$ ". The chromatographic behaviour of " $\mathrm{S}$ " is identical with that of authentic 2-pyridone-5-carboxamide-N'ribofuranoside using $0.1 \mathrm{mmol} / 1 \mathrm{HCOONH}_{4}, \mathrm{pH} 5$, with and without $\mathrm{MeOH}$ (volume fraction 0.05). The masses however are quite different: $m / c=304$ for " $S$ " and $\mathrm{m} / \mathrm{e}=270\left(\mathrm{M}^{+}\right)$for 2-pyridone-5-carboxamide- $\mathrm{N}^{1}$-ribofuranoside, the latter in accordance with Schlimme (personal communication).

The creatinine-related concentrations of ribonucleosides and " $\mathrm{S}$ " in urines of adults arc summarized in table 2. In no case was the slope of the regression lines (concentration versus age, calculated for each compound separately for females and males) different from zero between 1 and 40 years, thus indicating constancy of the urinary concentrations in adults. Furthermore, the values were normally distributed in both sexes. The creatinine-related concentrations of C, A, $\mathrm{m}^{2} \mathrm{G}, \Psi$, and " $\mathrm{S}$ " scem higher in women, but these differences were confirmed only for the last three substances (Student's t-tcst, significance level of $1 \%)$. Since the differences are very small, the values in females and males are considered together in the following calculations.

The concentrations of some ribonucleosides are correlated in pairs in adults. Relatively high correlations ( $r>0.6$ ) were found for the pairs $\Psi / \mathrm{m}^{2}{ }_{2} \mathrm{G}$ and $\mathrm{m}^{1} \mathrm{G} /$ $\mathrm{m}^{2}{ }_{2} \mathrm{G}$ (significance level of $0.1 \%$ ). The corrclation

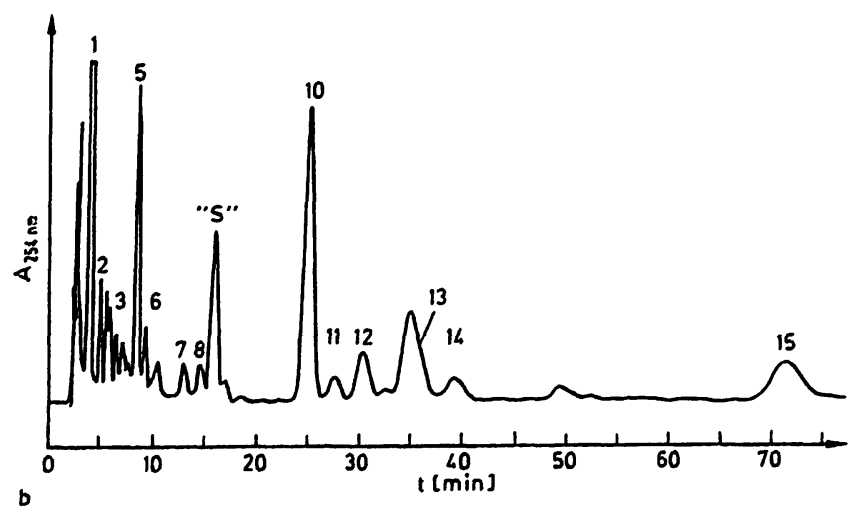

Identification:

1: Pscudouridine

3: Uridine

5: 1-Methyladenosine

7: Inosine

9: 3-Methyluridine

11: 1-Methylinosine

13: 2-Methylguanosine

15: $N^{2}, N^{2}$-Dimethylguanosine
2: Cytidine

4: 5-Aminoimidazole-4carboxamide riboside

6: 5-Methylcytidine

8: Guanosine

10: Tubercidine (IS)

12: 1-Mcthylguanosine

14: Adenosine 
between the concentration of other nucleoside pairs $(0.3>\mathrm{r}>0.6)$ was confirmed at least at the significance level of $1 \%$. The concentration of " $S$ " correlates weakly only with that of $\mathrm{C}$ and $\mathrm{m}_{2}{ }_{2} \mathrm{G}(\mathrm{r}=0.3$, significance level of $1 \%$ ). The corresponding Pearson coefficients are summarized in table 3.
Up to about 20 years of age, the urinary creatininerelated concentrations of ribonucleosides and the unknown substance "S" are age-dependent. They are much higher in infants than in adults (about 3-fold at one year compared with adults), decreasing rapidly in the first decade and only slowly thereafter (fig. 4).

Tab. 2. Creatinine-related urinary concentration of ribonucleosides and " $S$ " in adults (20th to 40th year). i,

\begin{tabular}{lccc}
\hline Substance & \multicolumn{2}{l}{ Concentration $(\overline{\mathrm{x}} \pm \mathrm{SD})[\mathrm{mmol} / \mathrm{mol}$ creatinine] } & females + males $(\mathbf{n}=81)$ \\
\cline { 2 - 4 } & females $(\mathrm{n}=33)$ & males $(\mathbf{n}=48)$ & $27.35 \pm 4.53$ \\
\hline Pseudouridine & $28.97 \pm 4.05$ & $26.24 \pm 4.54$ & $0.92 \pm 0.15$ \\
Cytidine & $0.97 \pm 0.18$ & $0.88 \pm 0.12$ & $1.00 \pm \frac{14}{ \pm}$ \\
1-Methylguanosine & $0.99 \pm 0.15$ & $1.01 \pm 0.14$ & $0.42 \pm 0.12$ \\
Adenosine & $0.44 \pm 0.12$ & $0.41 \pm 0.13$ & $1.20 \pm 0.19$ \\
$\mathrm{~N}^{2}, \mathrm{~N}^{2}$-Dimethylguanosine & $1.28 \pm 0.22$ & $1.15 \pm 0.15$ & $80.00 \pm 17.18$ \\
"S" & $89.94 \pm 17.2$ & $73.16 \pm 13.10$ & \\
\hline
\end{tabular}

Tab. 3. Pearson correlation coefficients (healthy adults).

\begin{tabular}{|c|c|c|c|c|c|}
\hline & Pseudouridine & Cytidine & $\begin{array}{l}\text { 1-Methyl- } \\
\text { guanosine }\end{array}$ & Adenosine & $\begin{array}{l}\mathrm{N}^{2}, \mathrm{~N}^{2} \text {-Dimethyl- } \\
\text { guanosine }\end{array}$ \\
\hline Cytidine & $\left.0.5383^{* *}\right)$ & & & & \\
\hline 1-Methylguanosine & $\left.0.4294^{* *}\right)$ & $\left.0.4773^{* *}\right)$ & & & \\
\hline Adenosine & $\left.0.3951^{* *}\right)$ & $\left.0.4183^{* *}\right)$ & $\left.0.3098^{*}\right)$ & & \\
\hline $\mathrm{N}^{2}, \mathrm{~N}^{2}$-Dimethylguanosine & $\left.0.6312^{* *}\right)$ & $\left.0.5695^{* *}\right)$ & $\left.0.6775^{* *}\right)$ & $\left.0.2707^{*}\right)$ & \\
\hline 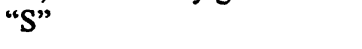 & 0.2586 & $\left.0.3017^{*}\right)$ & 0.0247 & 0.0298 & $\left.0.3175^{*}\right)$ \\
\hline
\end{tabular}

Significance level: $\quad *$ ) $1 \% \quad * *$ ) $0.1 \%$
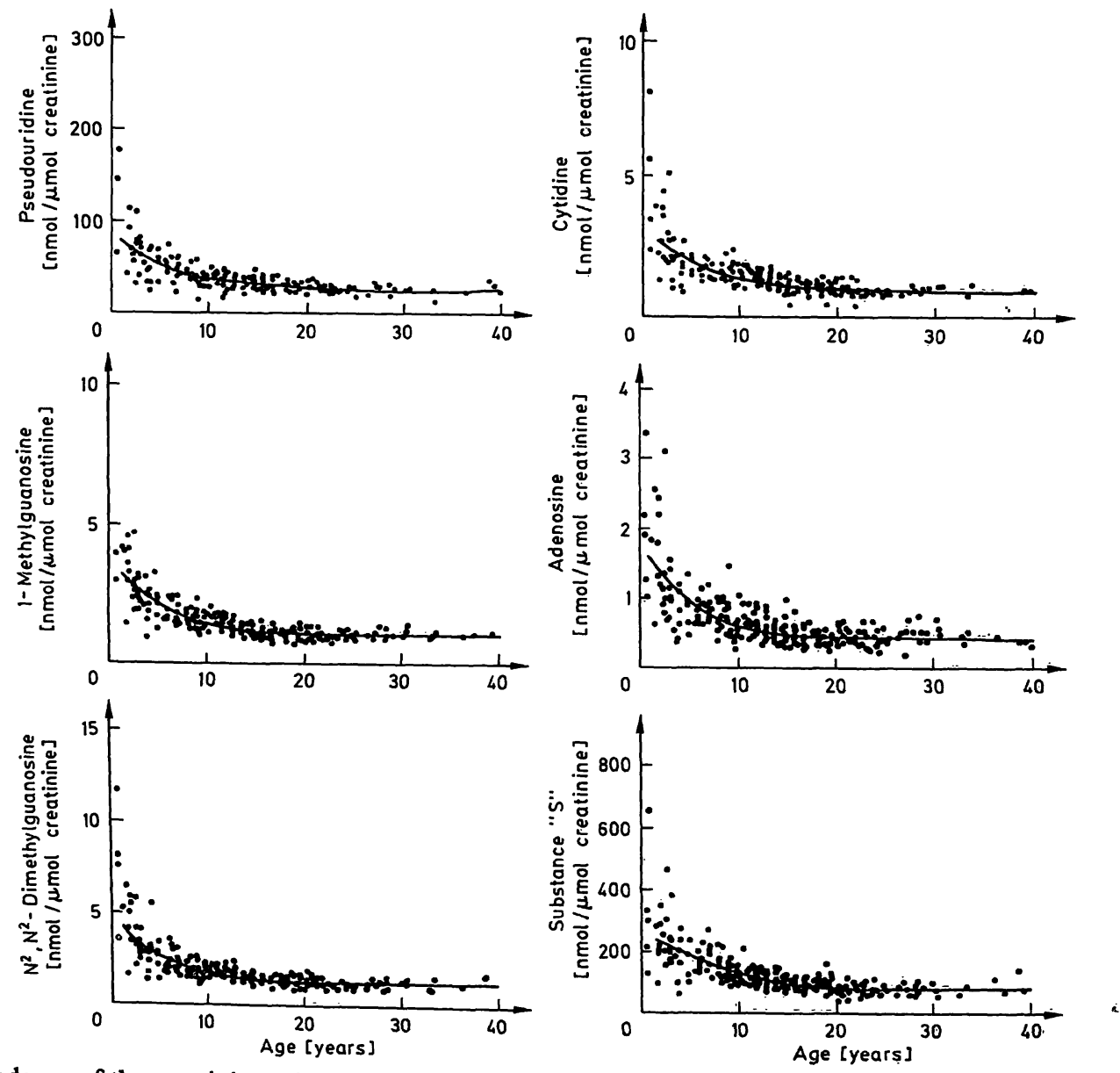

Fig. 4. Age dependency of the creatinine-related concentration of the ribonucleosides pseudouridine, cytidine, 1-methylguanosine, adenosine, $\mathrm{N}^{2}, \mathrm{~N}^{2}$-dimethylguanosine and an unidentified substance " $\mathrm{S}$ " in human urine. 
Tab. 4. Coefficients $\left(a_{0}\right.$ to $\left.a_{5}\right)$ for the calculated polynomials of the 5th degree $\left(y=a_{0}+a_{1} x+\ldots+a_{5} x^{5}\right)$. $x=$ age (years), $y=$ nucleoside concentration ( $\mathrm{mmol} / \mathrm{mol}$ creatinine).

\begin{tabular}{|c|c|c|c|c|c|c|}
\hline Substance & $a_{0}$ & $a_{1}$ & $a_{2} \cdot E-2$ & $a_{3} \cdot E-3$ & $a_{4} \cdot E-5$ & $a_{5} \cdot E-7$ \\
\hline Pseudouridine & 90.7965 & -11.3582 & 89.4017 & -35.7579 & 68.6442 & -49.5299 \\
\hline Cytidine & 3.2179 & -0.3775 & 2.6121 & -0.9022 & 1.5017 & -0.9466 \\
\hline 1-Methylguanosine & 3.7391 & -0.4364 & 2.8225 & -0.9134 & 1.4699 & -0.9350 \\
\hline Adenosine & 1.7257 & -0.1868 & 0.8996 & -0.1313 & -0.1186 & 0.3085 \\
\hline $\mathrm{N}^{2}, \mathrm{~N}^{2}$-Dimethylguanosine & 4.9962 & -0.6625 & 4.9201 & -1.8660 & 3.4997 & -2.5459 \\
\hline "S" & 267.6770 & -20.3109 & 68.9660 & -3.8660 & -20.3940 & 29.2180 \\
\hline
\end{tabular}

Since the variation of the creatinine-related nucleoside concentration is relatively high during the first year of life, these values have been excluded from the curve fitting. The rounded arguments $a_{0}$ to $a_{5}$ of the polynomial of the 5 th degree are summarized in table 4.

Figure 5 shows the fitted curves, expressed as the fraction of the function value of infants. The curves of the ribonucleosides as well of the unidentified substance " $S$ " are nearly coincident, thus indicating an unchanged excretion pattern throughout development.

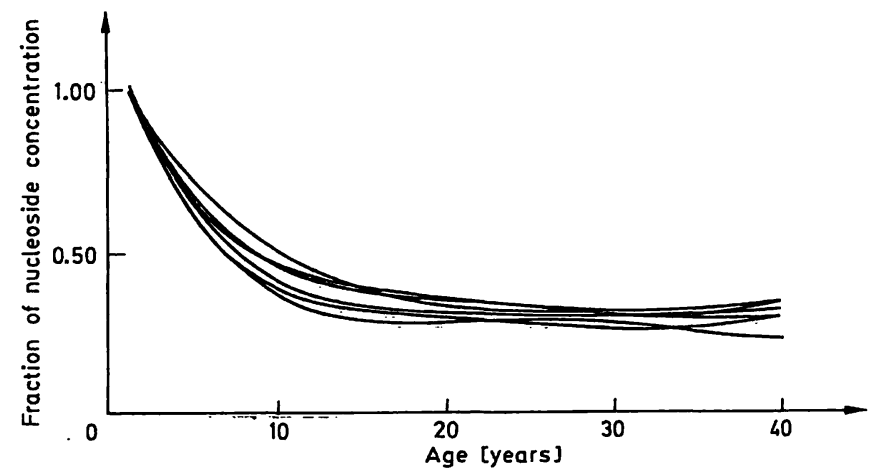

Fig. 5. Bundle of fitted curves (creatinine-related nucleoside concentration versus age) as the fraction of respective value at one year of age.

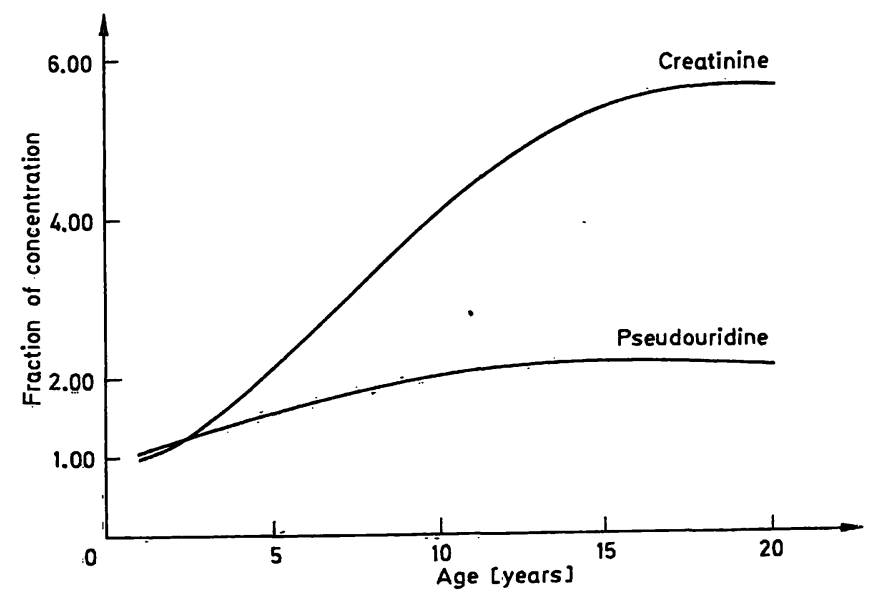

Fig. 6. Median pseudouridine and creatinine concentration of the analysed urines. Curves as the fraction of respective function value at one year of age.
The fitted curves of the concentration of creatinine and pseudouridine (as example for the remaining nucleosides) in the analysed urines, expressed as the fraction of function value at one year of life, are depicted in figure 6 . The creatinine level in adults is about six times higher than in one year old toddlers and it increases especially during the first decade. The pseudouridine concentration increases only twice as much and reaches a plateau between 10 and 15 years of life.

\section{Discussion}

We examined the urinary excretion of major and modified ribonucleosides and an as yet unidentified substance " $S$ " from 345 healthy probands of different ages. The data should supply basic information for investigations on the excretion of RNA degradation products for diagnostic purposes.

Earlier investigations have shown that creatinine, a measure of muscular mass (19), is a reliable baseline for the quantitative determination of RNA breakdown products in urine, as the relation between RNA catabolite and creatinine concentration in spot samples is very similar to that in 24-h urines $(6,20)$. One has to consider, however, that certain dietary regimens and pharmaceuticals influence the excretion of creatinine $(19,21)$, and that some pharmaceuticals can interfere with the determination of this compound (22).

The creatinine-related urinary concentration of nucleosides and the unidentified substance were found to be constant in adults (aged 20 to 40 years). Our data correlate quite well with data of other groups $(20,23,24)$. We cannot exclude the possibility that the nucleoside-creatinine ratio is influenced by the lower creatinine excretion in older people $(25,26)$. Results of Rasmuson et al. (27) seem to disprove this supposition, whereas Tritsch et al. found higher (about 3-fold) pseudouridine/creatinine values in older adults than in younger ones (28). 
Like Speer et al. (23) we found slightly higher values for some nucleosides in women, which contradicts the findings of other groups $(27,29)$. So it is not clear whether sex-dependent differences indeed exist.

In children and adolescents the creatinine-related concentration of nucleosides is obviously age-dependent. However the decrease of concentration is not linear as Heldman et al. (12) suspected, but can be described for each compound to a good approximation by a polynomial of 5th degree. The curves were calculated using the cubical spline function to get straight fitted curves without a fixed mathematical model, and to assure a sensible adjustment procedure for course deviations. In contrast to earlier investigations on the excretion of nucleobases, and despite higher case numbers, we observed no increase of the creatinine-related nucleoside concentration in puberty (fig. 4). The dynamics observed by Schöch et al. (13) may be caused by the native excreted nucleobases, which were determined together with the hydrolysed nucleosides. However this seems less probable, since the course of $\mathrm{N}^{2}, \mathrm{~N}^{2}$-dimethylguanosine equals that of the other nucleosides (fig. 5). So far, we have been unable to detect the corresponding base in any urine (unpublished results).

The courses of the creatinine-related concentration of the investigated nucleosides during development are nearly coincident (fig. 5). This suggests an unchanged excretion pattern throughout childhood and adulthood. According to observations of Sander et al. (30), this is also true of preterm infants, which contradicts earlier findings of a deviant nucleobase pattern during the first months of life (6).

As shown above, the concentrations of some ribonucleosides are relatively highly correlated in pairs. Consecutively we can describe not only an univariate but also a multivariate normal range. The usefulness of such a procedure for diagnostic purposes has been demonstrated by Müller et al. (7). Based on the calculated polynomials we are able now to ascertain any shift between nucleoside and creatinine excretion and also pathological changes in nucleoside excretion pattern caused by tumour growth or other diseases in infants as well in adults (Müller-Wickop et al., in preparation). Only two milliliters of urinary spot samples are needed for this purpose.

To interpret the age-dependent dynamic of the creatinine-related urinary ribonucleoside concentration we have calculated the curves of the underlying creatinine and pseudouridine concentration (representative for the remaining ribonucleosides) in the analysed urines. As shown in figure 6, the course of the concentration of both substances versus age is quite different. Whereas the creatinine concentration increases about 6-fold, the nucleoside concentration increases only two-fold from the first year to adulthood. This suggests a higher metabolism of ribonucleic acids in infants related to the muscular mass. Based on literature data concerning the creatinine output per body mass, Sander et al. (31) calculated that metabolism in preterm infants is about $2-4$ times higher than in adults.

The overall RNA metabolism, however, can be determined correctly only by measurement of the RNA catabolites in $24 \mathrm{~h}$ urines. It seems to be remarkable that the daily creatinine output appears about 3-4 fold higher in adults than in infants $(32,33)$. On the other hand, the creatinine-related nucleoside concentration is about 3-fold higher in infants than in adults, as shown above. So we can assume that the daily excretion of RNA catabolites is not very different in both groups. This supposition however remains to be proved.

\section{Acknowledgement}

We are indebted to the Bundesministerium für Forschung und Technologie, the Werner Otto Stiftung, Hamburg, and the Fördergemeinschaft zur Erforschung und Heilung von Krebskrankheiten bei Kindern e. V., Hamburg, for generous financial help.

We want to thank the former director of our group, Prof. Dr. G. Schöch, Dortmund, who initiated this investigation, and Prof. Dr. E. Schlimme, Kiel, for the gift of 2-pyridone-5-carboxamide- $\mathrm{N}^{1}$-ribofuranoside. We thank $H$. Wolff-Döttinchem and A. Holtgrewe for excellent technical assistance, Dr. Stritzke, Department of Radiology, for helpful discussions and the computer scientists of the department of haematology and oncology for assistance.

\section{References}

1. Hall, R. H. (1971) The modified nucleosides in nucleic acids. Columbia University Press, New York \& London.

2. Fasman, G. D. (Ed.) (1975) Handbook of Biochemistry and molecular biology (3rd edition). Nucleic acids. CRS Press, Cleveland.

3. Dirheimer, G. (1983) In o.c. (8), pp. 15-46.

4. Borek, E., Sharma, O. K. \& Waalkes, T. P. (1983) In o.c. (8), pp. $301-316$.
5. Salvatore, F., Colonna, A., Costanzo, F., Russo, T., Esposito, F. \& Cimino, F. (1983) In o.c. (8), pp. $360-377$.

6. Schöch, G. \& Heller-Schöch, G. (1977) Molekularbiologie und klinische Bedeutung des Stoffwechsels normaler und modifizierter Nucleobasen. Helv. Paed. Acta (Suppl. 38).

7. Müller, J., Erb, N., Heller-Schöch, G., Lorenz, H., Winkler, K. \& Schöch, G. (1983) In o. c. (8), pp. $317-330$. 
8. Nass, G. (Ed.) (1983) Recent Results in Cancer Research 84: Modified Nucleosides and Cancer. Springer, Berlin, Heidelberg \& New York.

9. Naylor, E. \& Lederbaum, S. D. (1981) J. Inher. Metab. Dis. 4, 207-210.

10. Hirschhorn, R., Ratech, H., Rubinstein, A., Papageorgiou, P., Kesarwala, H., Gelfand, E. \& Roegner-Maniscalco, V. (1982) Pediatr. Res. 16, 362-369.

11. Clemens, P., Schöch, G., Ziemer, G., Altenhoff, J., Erb, N., Lorenz, H., Müller, J. \& Grüttner, R. (1982) Pädiatr. Pädol. 17, 157-163.

12. Heldman, D. A., Grever, M. R., Miser, J. S. \& Trewyn, R. W. (1983) J. Natl. Cancer Inst. 71, 269-273.

13. Schöch, G., Lorenz, H., Heller-Schöch, G., Baisch, H. \& Clemens, P. (1981) Monatsschr. Kinderheilk. 129, 29-33.

14. Schöch, G., Thomale, J., Lorenz, H., Suberg, H. \& Karsten, U. (1980) Clin. Chim. Acta 108, 247-257.

15. Sander, G., Wieland, J., Topp, H., Heller-Schöch, G., Erb, N. \& Schöch, G. (1985) Clin. Chim. Acta 152, 355-361.

16. Hall, R. H. \& Dunn, D. B. (1975) In: o.c. (2), pp. 216250.

17. Stoer, J. (1972) Einführung in die numerische Mathematik I. Springer Verlag, Berlin, Heidelberg, New York.

18. Späth, H. (1973) Algorithmen für elementare Ausgleichsmodelle. Oldenbourg Verlag, München, Wien.

19. Heymsfield, S., Arteaga, C. A., Mc Manus, C., Smith, J. \& Moffit, S. (1983) Am. J. Clin. Nutr. 37, 478-494.

20. Gehrke, C. W., Kuo, K. C., Waalkes, T. P. \& Borek, E. (1979) Cancer Res. 39, 1150-1153.

21. Schilsky, R. L. (1984) In: Toxicity of Chemotherapy (Perry, M. C. \& Yarbro, J. W., eds.). Grune and Strutton, Orlando, San Diego, San Francisco.
22. Kroll, M. H., Olson, D., Rawe, M., King, C., Hagengruber, D. \& Elin, R. J. (1985) Clin. Chem. 31, 1900-1904.

23. Speer, J. E., Gehrke, C. W., Kuo, K. C., Waalkes, T. P. \& Borek, E. (1979) Cancer 44, 2120-2123.

24. Heldman, D. A., Grever, M. R., Speicher, C. E. \& Trewyn, R. W. (1983) J. Lab. Clin. Med. 101, 783-792.

25. Friedman, S. A., Rainzner, A. E., Rosen, H., Solomon, N. A. \& Sy, W. (1972) Ann. Int. Med. 76, 41-45.

26. Sato, T., Saito, K., Takezawa, J., Fujishama, T., Ijjima, T., Kuninaka, A. \& Yoshino, H. (1981) Clin. Chim. Acta 110, 215-225.

27. Rasmuson, T., Björk, G. R., Damber, L., Holm, S. E., Jacobsson, L., Jeppson, A., Littbrand, B., Stigbrand, T. \& Westman, G. (1983) In: o.c. (8), pp. $331-343$.

28. Tritsch, G. L., Luch, J. M., Evans, J. T. \& Mittelman, A. (1979) Biochem. Med. 22, 387-390.

29. Waalkes, T. P., Gehrke, C. W., Zumwalt, R. W., Chang, S. Y., Lakings, D. B., Tormex, D. C., Ahman, D. C. \& Moertel, C. G. (1975) Cancer 36, 390-398.

30. Sander, G., Heller-Schöch, G., Wieland, J., Topp, H. \& Schöch, G. (1985) In: Metabolism and Enzymology of Nucleic Acids including Gene Manipulations (Zelinka, J. \& Balan, J., Ed.) 5. pp. 365-375.

31. Sander, G. Hülsemann, J., Topp, H., Heller-Schöch, G. \& Schöch, G. (1986) Ann. Nutr. Metab. 30, 137-142.

32. Applegarth, D. A. \& Ross, P. M. (1975) Clin. Chim. Acta 64, 83-85.

33. Eanes, R. Z. \& Biniek, R. L. (1980) Biochem. Med. 24, 110-117.

Dr. rer. nat. N. Erb and

Dr. med., Dipl. Inform. J. Müller-Wickop Universitätskinderklinik Abt. Hämatologie und Onkologie Martinistr. 52

D-2000 Hamburg 20 
1

, i 